\title{
Sexos, sexualidades e gêneros: uma contribuição das teorizações feministas para a discussão dos limites das explicações e categorizações biológicas
}

\author{
Sex, sexualities and genders: a contribution of feminist theorizations for the \\ discussion of the limits of explanations and biological categorizations
}

Fabiana Aparecida de Carvalho ${ }^{1}$

\begin{abstract}
Resumo
O objetivo deste ensaio é discutir a centralidade dos gêneros e as contribuições ou limitações do campo semântico/científico da biologia e da cultura para definir categorias como gênero, sexualidades e sexo. Para tanto, ancora-se em teorizações advindas das epistemologias feministas e pós-críticas para apresentar/deslocar alguns enunciados sobre sexos e gêneros e pensá-los em sua ordem discursiva, ou seja, em como suas definições ou linguagem específica abrangem ou aprisionam outros significados e circunstanciam, muitas vezes, uma biologia normativa e determinística. Tal problematização também apresenta críticas sobre o entendimento binário dos sexos/gêneros, enfatizando modelos diferenciados lidos por biólogas feministas que criticam os entendimentos que se valem da biologia para construir sentidos sobre nossos corpos.
\end{abstract}

\section{Palavras chave: Gêneros; Sexualidades; Sexo; Biologia; Epistemologias Feministas}

\begin{abstract}
The purpose of this essay is to discuss the centrality of genders and the contributions or limitations of the semantic/scientific field of biology and culture to define categories such as gender, sexuality and sex. Thus, this research anchors in the theorizations coming from feminist and post-critical epistemologies to present and to displace some declarations about sexualities and genders and to discuss its discursive order, in other words, how their definitions or specific language embraces or imprisons other meanings and often circumscribes a normative and deterministic biology. This problematization also criticizes the binary understanding of sexualities / genders, emphasizing differentiated models read by feminist biologists who criticize the understandings that use biology to construct meanings about our bodies.
\end{abstract}

Keywords: Genders; Sexualities; Sex; Biology; Feminist Epistemologies

\footnotetext{
${ }^{1}$ Doutora em Educação - Universidade Estadual de Maringá. Maringá, PR - Brasil. Professora Assistente Universidade Estadual de Maringá. Maringá, PR - Brasil.Email: facarvalho@uem.br

Submetido em: 29/04/2020 - Aceito em: 10/06/2020
} 


\section{Introdução}

Muito do que molda uma pesquisa ou um fato científico advém do debruçar analítico sobre o objeto investigado num movimento articulado a referenciais teóricos e aos fenômenos que desejamos compreender. Muito do que pesquisamos, no entanto, relaciona-se com escolhas da vida (profissional e pessoal), ou, sob outra ótica, com as escolhas políticas que proferimos. Como bióloga, tenho me apropriado, hibridamente, das epistemologias feministas, especialmente de autoras mulheres, para pensar os meandros da Educação para os gêneros - as sexualidades - $e$ as diferenças no Brasil e para expor o uso de determinismos biológicos nas discursividades sobre a temática, principalmente no âmbito dispositivo da produção do conhecimento, das pedagogias culturais, de metodologias, de modelos, das ações pedagógicas, dos currículos e da formação de professoras/es. Essa é uma tarefa complexa, pois exige, em primeiro lugar, uma discussão acerca do fazer científico e de sua difusão como conhecimento.

Como sabemos, os campos científicos são espaços constituídos por posições, investimentos, instituições e interesses específicos que deslocam e definem redes de articulação, produção de fatos e o quê/quem será autoridade válida e terá o monopólio da competência específica para falar/fazer ciência. Sob esse aspecto, Donna Haraway nos alerta que "as fronteiras internas e externas do conhecimento são teorizadas como movimento de poder” (1995, p.02) e a produção de explicações é um lugar bordejado por relações de força que hegemonicamente corporificam a tendência de determinados pontos de vista.

Para efeito de exemplificação desse aspecto funcional do campo científico, basta observar, por exemplo, o fato de pesquisadores homens - supremamente destacados em publicações científicas - há muito definirem as pesquisas dominantes e o conjunto de teorias importantes na construção da ciência, impondo, na maioria das vezes, visões masculinistas, sexistas e normativas dos saberes que paulatinamente popularizam-se no meio acadêmico e nas pedagogias culturais. Somam-se, ainda, os delineamentos com vieses cientificistas a tornarem difícil a compreensão dos gêneros, ou da construção da ciência pela perspectiva dos gêneros como saberes situados - gendrados e influenciados por articulações que se diferenciam em cada grupo ou atravessamento cultural - e como elemento constitutivo do saber científico (LÖWY, 2009; HARAWAY, 1995; KELLER, 2006; LIMA E SOUZA, 2008). Junto a essa dificuldade, há uma forte tendência em reproduzir as ideias de neutralidade, objetividade e as explicações dos fenômenos naturais em convenções padronizadoras de nossos modos de ser e ocultar categorias relacionais, tanto a própria parcialidade na produção do conhecimento, quanto os gêneros, a corporeidade, a diversidade sexual e as interseccionalidades de classe, idade, etnia e raça, por exemplo.

$\mathrm{Na}$ contramão dessas (im)posturas científicas, as epistemologias e teorizações feministas denunciam o androcentrismo científico e suas consequências. E mais: articulam-se à produção das ciências - especialmente aquelas mobilizadas por mulheres, por países considerados periféricos ou do sul global, por cientistas não brancos e por representações 
culturais que respaldam o direito das minorias sociais e o acesso aos saberes diferenciados e contra hegemônicos. Assim, trabalhos de biólogas e filósofas da ciência, a citar, os de Donna Haraway (1995), Evelyn Fox Keller (2006), Londa Schienbinger (2001), Sandra Harding (1996) e Angela Maria Freire de Lima e Souza (2008), apontam as questões estruturais e estruturantes da ciência firmadas em binarismos de sexo/gênero, denunciam os preconceitos, a subalternização cognitiva, profissional e a apropriação da força de trabalho de mulheres cientistas, e perfazem a produção de teorias situadas e os efeitos políticos de uma prática científica alinhada a partir da perspectiva feminista. Tais posições (e)levam os entendimentos sobre sexualidades, gêneros e alteridades produzidos junto ao conhecimento científico para um campo de categorização e de embate político, social, pessoal e subjetivante.

Essa conjuntura, que toma os gêneros como ferramentas analíticas, é propícia para se pensar na dispersão de sentidos e significados acerca dos sexos e dos gêneros e em certas confusões semânticas proferidas por enunciados e formações discursivas gestadas, em primeira instância, nos centros de produção da ciência - em particular os das Ciências Biológicas, mas adensadas posteriormente nas representações culturais. Essa é uma inquietação que me faz indagar constantemente se seria a biologia a melhor via explicativa para a Educação para os gêneros - as sexualidades - $e$ as diferenças, principalmente por ter sido essa, em boa parte como uma ciência de origem, a fixadora do entendimento binário sexo/gênero, da matriz política e social heterossexual, de conceituações e classificações que estabeleceram diferenças e preconceitos direcionados ao corpo - tomado, muitas vezes, mais por sua organicidade fisiológica e sistêmica do que propriamente por sua potência relacional, por seu caráter autopoiético ou por seus campos de subjetividade também merecedores de um olhar dito biológico.

Apesar dessa consciência, creio ser importante volver a mirada e buscar aproximações nas atribuições ou nas limitações da biologia quanto à definição das categorias ou dos conceitos que também ultrapassam seus limites classificatórios, epistemológicos, de representação ou mesmo de ensino, e criam, junto a outros bordejamentos de significados, os nossos sentidos e os nossos processos corporais, sexuais e generificados.

Logo, o objetivo desta comunicação é discutir a centralidade dos gêneros e as contribuições ou limitações do campo semântico/científico da biologia e da cultura para defini-los. Para tanto, o presente ensaio guia-se pelas teorizações feministas, na voz das mulheres aqui destacadas e, em segundo plano, na voz de teóricos pós-críticos ${ }^{2}$, para

\footnotetext{
${ }^{2}$ Neste ensaio, a epistemologia feminista deriva dos (e é reconhecida nos) campos da epistemologia social, das militâncias e do que os Estudos de Gênero têm considerado, além das críticas sobre a construção normativa de masculinidades e feminilidades e desigualdades sociais, e como as questões de gênero influenciam as concepções de conhecimento, as pesquisas e as produções científicas. As teorias pós-críticas são compreendidas como um conjunto de teorizações responsáveis por questionar os limites das teorias críticas e marxistas ao trazer, para o cerne de suas discussões, as problematizações das relações de poder na educação, a multiculturalidade, os debates interseccionais de classe, raça, etnia, gênero e subjetividade, o entendimento da produção discursiva e os limites linguísticos para a representação de determinadas categorias, a centralidade das questões culturais e as dinâmicas dos efeitos de poder, controle e disciplina tanto na produção da ciência quanto no campo educacional.
} 
apresentar/deslocar alguns enunciados sobre sexos e gêneros e pensá-los em sua ordem discursiva, ou seja, em como suas definições criam verdades, abrangem ou aprisionam outros significados e circunstanciam, muitas vezes, uma biologia normativa.

\section{0 (des)assertivo tom da biologia}

Qualquer pessoa formada em Ciências Biológicas ou com boas aulas no Ensino Médio aprendeu, ao menos em algum instante ou subárea desse campo do saber, que o sexo e a sexualidade, ao nível da reprodução, por exemplo, são as chaves para a variabilidade genética e para comportamentos que permitem a alguns seres vivos estratégias adaptativas aos ambientes; aprendeu também que corpo e gênero são categorias estruturantes de dogmas, pensamentos e de explicações da área, e que a sexualidade humana é um mosaico composto por fatores inatos, personificados, subjetivos e culturais. Entretanto, a biologia não é, em si mesma e isoladamente, a ferramenta conceitual mais precisa para definir tais categorias, especialmente porque arrasta uma sobreposição de enunciados e discursos em seus campos semânticos. Sendo, sobretudo,

um signo linguístico para uma estrutura complexa de crença e prática por meio da qual [...] organizamos uma grande parte da vida. A biologia não é também um discurso universal livre da cultura, pois ela tem considerável poder cultural, econômico e técnico para estabelecer o que será considerado como natureza por todas as partes do planeta Terra. A biologia não é o discurso de todo mundo sobre carne, vida e natureza humana, animal e vegetal; na verdade, carne e vida e natureza não estão menos enraizadas em histórias, práticas, línguas e povos do que a própria biologia. [...] Nenhum mundo-objeto natural fala sua verdade livre de metáfora e livre de estória por meio da objetividade sóbria da ciência livre da cultura e, portanto, universal (HARAWAY, 2017, p. 51).

$\mathrm{Na}$ sinalização dessas contradições acerca da construção do conhecimento biológico, de suas ficções ou ligações sociais e das tensões de seus posicionamentos tecidos em arenas culturais e vontades de saber, faz sentido posicionar que a biologia não dirá, com exclusividade, as verdades universais dos sexos e dos gêneros porque ela é uma verdade em trânsito e sujeita a alterações conforme grupos científicos, culturais, épocas distintas ou apropriações particulares, endereçadas e plenas de interesses se posicionam.

$\mathrm{Na}$ atualidade, os sexos, as sexualidades e os corpos são alvos de acepções e de significados diversos e, assim sendo, é possível que várias teorias derivadas das ciências de origem se encontrem em debates, em deslocamentos, em "xeques-mate" ou rasuradas, principalmente aquelas tidas como sexuais e/ou de gênero e as categorizações e binarismos marcados por limitações, arbitrariedades e/ou criações da linguagem biológica, como por exemplo, as categorias binárias: homem-mulher; natureza-cultura; sexo-gênero; branco-negro, já que "nossas concepções da natureza das diferenças de gênero moldam, e ao mesmo tempo refletem, a construção de nossos sistemas sociais e políticos [...] e a nossa compreensão de nossos corpos físicos" (FAUSTO-STERLING, 2006, p.65, tradução minha). 
Nessa amálgama, os aspectos biológicos e culturais não se excluem, mas se interdependem de maneira que não podemos considerar sexo, sexualidade, corpo e gênero como características, definições ou modos de ser exclusivamente biológicos. Visando a uma compreensão inter-relacional, tanto a cultura quanto a biologia se retroalimentam para garantir (ou para que sejam compreendidos) aspectos adaptativos inerentes à nossa espécie e negociáveis em nossas sociedades. No entanto, as descrições ou materialidades que acreditamos serem feitas ou constituídas exclusivamente de sôma e de natureza são, para as teorizações feministas e pós-críticas, efeitos de linguagem a criar uma história (não) natural daquilo que nos marca como pessoas.

Embora essa relação construcionista e conciliatória permita vislumbrar corpo, sexo, gênero, desejo, alteridade, entre outras questões, de maneira mais empática, no nível das explosões discursivas em torno dessas categorias, no aspecto social a biologia acaba por ser tracionada tanto como um dispositivo pedagógico ${ }^{3}$ quanto um mecanismo de controle. Pedagógico porque faz parte da produção de sentidos, representações e significados científicos, culturais e políticos difusos nas mais diferentes instâncias que irão nos ensinar modos de entender o mundo e de nele ser/estar. De controle, pois sua apropriação pode impor vieses deterministas marcados por investidas biopolíticas de observação, de regulamentação e de fiscalização; assim, a biologia sustentará discursos e dará "substratos a outras narrativas que, se não partem dela, utilizam-se de e se reforçam com seus elementos" (SANTOS, 2000, p. 243).

Quando volvemos aquilo que é ensinado na escola e nas pedagogias culturais, percebemos que os primeiros entendimentos, ao menos os considerados científicos, sobre corpo, sexo, sexualidades, gêneros, corporeidades e diferenças, são formatados nesses espaços e por intermédio de suas bio-logias. De fato, não há uma única biologia na escola e na cultura. Entretanto, o corpo e a vida ordenam-se em regras, explicações e conceitos que determinam quem ou o que pode ser considerado um organismo, quais sistemas, órgãos, células merecem ser estudados e classificados em complexos grupos, quais fisiologias importam aos processos vitais e ao funcionamento dos seres. Nesse emaranhado de definições, quais entendimentos se adensam e se visibilizam nas explicações desses saberes?

Conforme apontado anteriormente (CARVALHO; LORENCINI-JÚNIOR, 2018), de um lado, temos os corpos consagrados por atravessamentos de informações e codificados por bases bio-genéticas. São os corpos produtivos, considerados normais, brancos, heterossexuais, masculinos ou sem gêneros, desejos, infâncias, velhices, sensações e subjetividades, ou seja, corpos padronizados. Por esse prisma, na biologia ensinada na escola, mulheres, homens e crianças são corpos-sistemas parados, estáticos, modelizados em ilustrações, gráficos,

\footnotetext{
3 Ganha o nome de "dispositivo" um conjunto de práticas discursivas e não discursivas que empregam tecnologias de sujeição e ordens reiterativas das normas vigentes. Nas teorizações de Michel Foucault (1988), os dispositivos estão dispostos em processos de saber-poder que visam tanto à regulação do corpo individual como da população por uma série de regras, discursos e controles populacionais. Essa regulação é o governamento exercido por certas instâncias, entre elas a escola, e é denominada pelo autor de biopolítica.
} 
classificações e conceitos. De outro lado, apresentam-se os corpos com materialidades distintas, generificados, mulheres, jovens, sadios, doentes, idosos, cansados, transmutados que causam estranhamentos e escapam das classificações, com limitações diversas, sadios e/ou doentes, atravessados pelas implicações biológicas, mas também plenos de vontades, dores, alegrias e punções; são os corpos plurais os verdadeiros ocupantes das escolas. Nas práticas culturais que povoam a escola, a biologia, portanto, é outra... Os corpos tornam-se inclassificáveis, vivem e se organizam para além de seus funcionamentos fisiológicos ou das explicações determinísticas.

Quando convencionalmente se pensam nos currículos e nas abordagens pedagógicas, essas contradições ficam mais evidentes, porém muitos corpos, sexualidades, diferenças e gêneros desaparecem ou são inviabilizados (por conta das visibilidades e das classificações predominantes). Persiste, ainda, a norma curricular que elege as explicações biológicas, os territórios do ensino de ciências, as docentes de disciplinas afeitas como as agentes e os locais privilegiados na construção de saberes e de respostas sobre os corpos, as sexualidades, os gêneros. Para Judith Butler (2012), essa normatização se superpõe, apoiada pela biologia, como uma investida de poder por sobre outros corpos, tomando-os em função de ideais regulatórios que lhes impõem uma materialidade a ser governada e os subordinam a uma sociedade que exclui compulsoriamente aquilo que a norma classifica e patologiza.

Pari passu, as críticas apontadas pelas pesquisas acadêmicas (CARVALHO; LORECINI-JÚNIOR, 2018; CARVALHO; BERTOLLI-FILHO, 2011) quanto ao ensino desses temas e conteúdos, principalmente as que recaem sobre as partições fisiológicas e sistêmicas do corpo isentas de suas potências autopoiéticas, sobre o caráter biologizante e anato-fisiológico da reprodução e das sexualidades, e, sobretudo, as críticas em relação ao excessivo enfoque na prescrição médica de prevenção de infecções e doenças sexualmente transmissíveis, aliadas às dificuldades formativas, à pressão de dogmas religiosos ou de senso comum e à perda do status de conteúdo em função das discussões transversais, fazem-me voltar à perquisição se seriam os espaços-tempos do ensino de ciências e da biologia realmente os favorecedores do estabelecimento da centralidade da Educação para os gêneros - as sexualidades - e as diferenças na escola.

Responder a essa pergunta significa problematizar os efeitos dos dispositivos discursivos - as linguagens - presentes nos campos biológicos e culturais. Passa por essa via a discussão da essencialização da palavra sexo, a negação de outras dimensões das sexualidades e dos gêneros e a crítica ao cunho genital-reprodutivo apreendido por muitos grupos sociais como a norma válida do corpo ao longo da história toda da humanidade. 
DOI: https://doi.org/10.46667/renbio.v13i1.313

\title{
3 O deslizante nome das coisas... A perigosa ordem das palavras... A provisoriedade das explicações...
}

Do ponto de vista histórico ou mesmo linguístico, considerando tanto a ciência como nossas sociedades alinhadas ao patriarcalismo, a normatividade do sexo circunscrita à reprodução seria conspiradora de uma falácia que tem dominado nossos sentidos sobre as sexualidades: aceitar como estritamente possível, normal, natural e compulsório o envolvimento afetivo-sexual entre pessoas do gênero oposto, ou seja, a heterossexualidade; a heteronorma ou, conforme denominou Michel Foucault (1988), o dispositivo compulsório de controle dos sexos e dos gêneros para ordenar uma lógica produtiva e econômica dos corpos. Além disso, tal postura traz outras implicações e limitações normativas:

\begin{abstract}
1) legitima apenas a vida sexual daquelas pessoas que estão em período reprodutivo, ou seja, na adolescência e na vida adulta, e desconsidera a possibilidade de vivência da sexualidade na infância e na terceira idade; 2) legitima a prática sexual com penetração vaginal como, indiscutivelmente, 'a única' e 'a melhor', favorecendo o preconceito a outras práticas sexuais e a masturbação; 3) acentua a incompreensão da possibilidade de pessoas do mesmo sexo estabelecerem relacionamentos afetivos e sexuais; 4) dificulta o entendimento e a aceitação de uma sexualidade objetivando o prazer, sem a intencionalidade de filhos; 5) engessa a ideia de família como sendo aquela que, necessariamente, é constituída de um homem, uma mulher e filhos" (FURLANI, 2003, p. 73-74).
\end{abstract}

$\mathrm{Na}$ ordem dos discursos e dos significados das palavras e das coisas, os sentidos precisam ser criados para estabelecer códigos de uso ou de restrição, interditos, invenção de verdades para a sociedade e formas de compreensão. Não obstante, a biologia também opera por esse sistema de classificação, interdição ou de autorização da fala (CARVALHO, 2018).

Um instigante exercício para a percepção do vínculo construído culturalmente entre sexualidade - reprodução - sexo biológico - linguagem e para sua desessencialização é a constatação e o deslocamento das acepções da palavra sexo presentes nos dicionários. Com esse apoio, destaco algumas definições encontradas nos léxicos instrumentalmente mais acessíveis e com os quais estamos habituados a trabalhar, a realizar consultas e a construir as definições utilizadas nas pedagogias escolares e culturais (CARVALHO, 2018, p. 173):

- Dicionário Aurélio: condição de sexual; conjunto de fenômenos da vida sexual; sensualidade; sexo.

- Dicionário Houaiss: qualidade do que é sexual; conjunto de caracteres especiais, externos ou internos, determinados pelo sexo do indivíduo; sexo; conjunto de excitações e atividades presentes desde a infância (de um indivíduo), que está ligado ao coito, assim como os conflitos daí resultantes;

\footnotetext{
- Dicionário de Etimológico de Biologia - 'Soares': pertinente ao sexo; conjunto de atributos físicos, psicológicos e comportamentais que identificam um sexo do outro.
} 
DOI: https://doi.org/10.46667/renbio.v13i1.313

\begin{abstract}
- Biblioteca Virtual em Saúde (BIREME) - Descritores em Ciências da Saúde (DeCS): funções sexuais, atividades, atitudes e orientações de um indivíduo; a sexualidade, masculina ou feminina, se torna evidente na puberdade sob as influências dos esteroides gonadais (testosterona ou estradiol) e dos efeitos sociais.
\end{abstract}

- WIKIPEDIA (Enciclopédia Virtual Livre): A sexualidade de um indivíduo define-se como sendo as suas preferências, predisposições ou experiências sexuais, na experimentação e descoberta da sua identidade e atividade sexual, num determinado período da sua existência.

Tanto a palavra sexualidade quanto a palavra sexo são termos que deslizam numa rede flutuante de significações. Particularmente, com a associação de outros termos e enunciados, ampliam-se nessas palavras as conotações e seus vínculos à condição de sexual, de sensual e de atributos fisiológicos calcados na reprodução. É preciso, pois, volver o olhar a essa construção semântica e ao fato de os dicionários (livros didáticos, paradidáticos, panfletos, campanhas de saúde, enunciados biológicos) também produzirem cadeias de significação, projetando culturalmente sentidos e significados que irão incidir, moldar e definir o que entendemos e fazemos como Educação para os gêneros - as sexualidades - e as diferenças.

Nesse sentido, nenhuma tradução/explicação acaba sendo, pois, inocente e sem vieses pré-estabelecidos... Ao contrário, vincula-se a grupos e setores bem particulares em nossas sociedades. Sexo, sexualidade, gênero, corpo, longe de serem unidades essenciais, são, como categorias, práticas discursivas muito específicas (MOORE, 1994).

Esses termos, circunscritos por definições e conceitos, devem ser pensados em suas contingências, porque certamente dependem da junção das condições históricas, das relações sociais, das relações e sentidos de grupos culturais, das subjetividades, dos afetos, das angústias, do medo, das proximidades com outros seres humanos, das fases de nossas vidas, das políticas e ideologias, das aceitações ou recusas, visões de mundo, justamente porque possuímos alter(idades), afin(idades), maior(idades), afetiv(idades), complex(idades), subjetiv(idades) e histor(idades), e particularmente "de formas de sociabilidade, de política e de identificação que desvinculem o eu dos discursos dominantes da biologia, da natureza e da normalidade" (BRITZMAN, 2003, p. 73).

Apesar das intersecções identitárias subjetivas e interculturais e dos apontamentos dos jogos polissêmicos apropriados em variadas negociações e necessidades, nas escolas e nas pedagogias culturais, de um modo geral, a convencionada explicação biológica sobre a constituição do sexo, da sexualidade e do corpo na espécie humana esbarra nas e está definida pelas definições conceituais pautadas na procriação, na cópula, no desenvolvimento humano e a partir dos estudos genéticos, embriológicos e da fecundação. Contudo, esse aspecto pode ser capcioso e confundir 
DOI: https://doi.org/10.46667/renbio.v13i1.313

não só por estar literalmente relacionado (quase sempre, mas não exclusivamente) com a mistura de dois seres distintamente diferentes, [...] mas também por tendermos a fazer extrapolações equivocadas sobre a importância da sexualidade. Nossa existência biologicamente restrita de seres que se reproduzem sexualmente não significa, por exemplo, que exista apenas o sexo copulatório, baseado nos órgãos genitais, nem que o sexo esteja necessariamente relacionado com a reprodução. Na verdade, a maioria dos comportamentos de quatro dos cinco reinos de seres vivos não precisa dele para se reproduzir (MARGULIS; DORION, 2002, p. 12).

Além do mais, ao nível conceitual elementar das Ciências Biológicas, o sexo é considerado a recombinação genética durante a união ou a troca de genes; em processos naturais ou artificialmente manipulados, quando se tem a junção dos núcleos das células reprodutivas na fecundação dos organismos, com intermediação da permuta do DNA contido nos cromossomos, e um novo ser vivo é produzido no processo denominado de reprodução sexuada.

Perdura também, em meio ao superficialismo e às explicações equivocadas desses processos reprodutivos sexuados, o senso restrito ao dimorfismo sexual de machos e fêmeas; só que nem sempre a reprodução sexuada vai requerer sexos/indivíduos separados, uma vez que várias espécies são esporádicas ou permanentemente hermafroditas ou monoicas.

Considerando outras acepções biológicas, vale sinalizar que, no âmbito da escolarização básica, perfizemos e validamos a composição de nossas noções sobre sexo coligadas ao sistema cromossômico XY, válido somente para a determinação em alguns mamíferos. Desde lá, congregamos os símbolos advindos da genômica e do estudo dos cariótipos - XX para a representação de uma fêmea homogamética e XY para o macho heterogamético - como a configuração dos dois sexos biológicos possíveis para a espécie humana.

Conforme também sabemos, esse padrão, no entanto, não é universal e seu entendimento prescinde de um complexo conjunto de informações genéticas e embriológicas que perfazem explicações para muito além da discursividade cultural a congregar metáforas sexistas das ações dos genes.

Em aves, crustáceos e alguns insetos, por exemplo, predomina o sistema ZW e são as interações químicas decorrentes do ovócito que determinarão o sexo das fêmeas heterogaméticas ZW ou dos machos homogaméticos ZZ. Em outros organismos nos quais prevalece a ausência $\mathrm{Y}$, os machos possuem números cromossômicos ímpares e a herança na descendência obedece ao sistema XO. Em outras espécies, ainda, o genótipo não se traduz no fator determinante de sexo biológico; o tamanho dos gametas em alguns vegetais pode ser um fator decisivo; em outros seres, a temperatura e as interferências físicas e químicas nos ambientes, por exemplo, é que são importantes na determinação do sexo e do desenvolvimento embrionário distinto (caso das tartarugas). Há também a correlação de agentes teratogênicos, como poluentes e agroquímicos, que poderão atuar como promotores 
ou inibidores hormonais e induzir a troca de sexo mediante complexos mecanismos de alterações nos hormônios esteroides sexuais.

Espaçando a explicação, para o grupo mamífero é usada, a rigor, a descrição da junção de gametas (ovócito com o espermatozoide conformarão o zigoto) como o conhecimento da ideia de sexo ou de definição sexual. A primeira célula após a fecundação contém, pois, os genes provenientes da fêmea e do macho da espécie e, por sucessivas clivagens, diferenciações celulares e complexas combinações químio-proteicas, formará o embrião de um futuro ser.

É sabido que para a produção das células reprodutivas, o número cromossômico da espécie humana (46 cromossomos) é reduzido à metade em processos metabólicos de meiose e mitose celular realizados nas gônadas. Na espécie humana, a ovogênese é o fenômeno que ocorre em fêmeas a partir do início da vida fetal com o amadurecimento das ovogônias em ovócitos primários, os quais iniciam a primeira divisão meiótica ainda antes do nascimento e completam sua síntese, sob influência de hormônios do hipotálamo, da hipófise e esteroides, quando se inicia o ciclo reprodutivo adulto. Essa fisiologia dá origem a ovócitos que carregam 22 cromossomos autossômicos e um sexual X (padrão $22+X$ ). Nos machos, é a espermatogênese, que ocorre nos testículos, o transcurso gerador de espermatogônias, as quais somente maturam, sob influência dos hormônios gonadotróficos da hipófise, do hipotálamo e dos androgênicos testiculares, na puberdade. Sucessivas divisões meióticas e mitóticas farão com que cada espermatogônia dê origem a quatro células espermáticas com 22 cromossomos somáticos e um sexual. Metade dos espermatozoides contém o cromossomo Y, contribuinte para a determinação de machos da espécie (padrão $22+\mathrm{Y}$ ) e a outra metade carrega $\mathrm{o}$ cromossomo X, co-atuante para conformar a fêmea $(22+\mathrm{X})$. O chamado sexo biológico da pessoa descendente, de acordo com este modelo explicativo, seria influenciado pelo tipo de espermatozoide que fertilizaria o ovócito. Ocorrendo a fecundação, o número da espécie é restaurado no zigoto (que poderá ser $46 \mathrm{XX}$, caso a configuração seja de fêmea, ou $46 \mathrm{XY}$, caso seja de macho, ou variações que demandam intersexualidades). Convencionalmente, esse modelo perfaz as explicações de um processo biológico denominado de sexo genético ou cromossômico.

Aprendemos essa lógica dimórfica desde muito cedo, porém, é válido elucidar que existem vários outros modelos e pesquisas em discussão nas academias e laboratórios, e muitos deles criticam a explicação da determinação sexual intrinsecamente ligada aos gametas masculinos, ao considerar como coadjuvantes a bioquímica ovular, as interações nucleares e gênicas e a influência de cromossomos zigóticos autossômicos no desenvolvimento sexual embrionário. 
A bióloga feminista Anne Fausto-Sterling (2012) aponta que outras descobertas recentes sobre a aparelhagem bioquímica e neurológica ainda corroboram para evidenciar que não há diferenças moleculares regulares entre os sexos. Essa concepção científica de que o fator determinista se encontra presente no cromossomo $\mathrm{Y}$ e ausente no $\mathrm{X}$, tanto na biologia como nas representações que circulam por várias pedagogias, produz, via linguagem explicativa, uma matriz sexista e preconceituosa na descrição da fertilização e dos nascimentos, especialmente os humanos. Também contribui, sem que percebamos, para o decalque de significados culturais e de posturas sociais arbitrárias esperadas para mulheres e homens desde a concepção. Nessa metáfora subsidiada pela ciência, enuncia-se, ainda, o espermatozoide como célula ativa, ágil, forte, competitiva e conquistadora, enquanto se denota o ovócito espelhado em características antagônicas, como frágil, pálido, fraco, passivo e reservado num propositado decalque das performances e papéis sociais aludidos a homens e a mulheres.

Feito o destaque, é prudente ressaltar que a linguagem, mesmo a científica, é capciosa e apresenta limites para sintetizar como verdade uma única teoria a dizer das construções de nossos corpos, sexos e gêneros.

Ainda em função do desenvolvimento, outras categorizações e sentidos de sexo são também apontados pela biologia enquanto campo de origem.

Conforme descreve a embriologia, a partir do início do segundo mês gestacional, após várias clivagens, formação de folhetos embrionários e esboço de alguns tecidos e órgãos, ocorre a diferenciação sexual para as gônadas e para a conformação da genitalidade; a expressividade $\mathrm{Y}$ e as influências fisiológicas do androgênico testosterona são alguns dos fatores específicos, porém não os únicos determinantes, para o desenvolvimento de testículos e da genitália macho e para a inibição da diferenciação celular na formação dos ovários, útero e da genitália fêmea. A manifestação dos testículos ou dos ovários está descrita nessa explicação (ou representação) que ganha a alcunha de sexo gonádico.

O sexo fenotípico, outra categoria descritiva, abarca as características físicas do trato interno e externo; o trato genital interno que inclui a próstata, glândula seminal, ducto deferente e epidímico mais a genitália externa formada pelo escroto e pelo pênis compõem os caracteres fenotípicos para os machos de nossa espécie. Já nas fêmeas, a genitália interna é conformada pela tuba uterina, útero e a parte interna da vagina, e a externa seria constituída pela abertura da vagina, pelo clitóris, pelos grandes e pequenos lábios. Do ponto de vista da morfo-fisiologia, o sexo fenotípico ainda teria sua expressão influenciada pelo denominado sexo hormonal, que abrange a atuação dos hormônios gonadotróficos estrógeno, progesterona e testosterona, especialmente a partir da puberdade e da adolescência, quando esses coparticipam no início do ciclo reprodutivo e nas expressões secundárias relacionadas à conformação adulta da espécie humana.

Há que se considerar que a determinação do chamado sexo biológico é muito flutuante e variável e, na busca de características diferenciadoras, 
certos aspectos são naturalizados por um discurso que tende a colocar sobre a biologia a responsabilidade pelas diferenças atualmente percebidas entre o que entendemos por homem e mulher ou por masculino e feminino, prescrevendo uma concepção do corpo fundamentalmente pautada pelas explicações biológicas, sem que aspectos sociais, culturais e políticos sejam considerados em sua devida relevância (SENKEVICS; POLIODORO, 2012, p. 12).

O panorama explicativo apontado com essas descrições dos sexos cromossômico, gonádico, fenotípico e hormonal, bem como dos sistemas de determinação, é uma síntese resultante de bases, informações, modelagens, conceitos e explicações de áreas que recorrentemente são acionadas para explicar o desenvolvimento sexual, pelo menos nos últimos dois séculos - a genética, a embriologia e a fisiologia, entre outras. Essas nos auxiliam a compreender que na influição de nossas expressões inatas, fenotípicas e instintivas há muito que se considerar, biologicamente falando, inclusive o controle epigenético ${ }^{4}$ que pode inativar a expressão de genes, moléculas e fatores químio-fisiológicos do corpo.

Por outro lado, como modelagens eleitas pela própria biologia (e como conteúdos curriculares em escolas), não são muito eficazes para ajustar nossas lentes e direcionar os olhares para outras materialidades corporais que escapam, borram ou desconstroem as supostas precisões ontológicas ou as concepções binárias apoiadas em hierarquias de poder, essencialismos e em diferenças de natureza/biológicas (em relação ao sexo) e culturais (em relação aos gêneros), como exemplo, a manifestação da vida intersexual e a condição de transgenerificação expressa por muitas pessoas que não se reconhecem como cisgêneras ${ }^{5}$, ou seja, pessoas que apresentam configurações de gênero não coincidentes com o sexo biológico atribuído ao nascimento.

Ademais, considerando o campo de tensões desses saberes na tentativa de definir e criar a vida e os sexos que importam (BUTLER, 2012), não podemos esquecer que os conhecimentos advindos das áreas citadas e suas sistemáticas deram, principalmente às pessoas médicas, biólogas e outras especialistas, o controle sobre a definição dos sexos dos corpos e sobre as linguagens, conceituações e informações que validariam seus gêneros como verdades científicas.

Nesse quesito, conforme aponta Anne Fausto-Sterling (1993, p. 21, tradução minha), a ciência e as instituições sociais: "[..] estão interessadas em manter um sistema sexual bipartido, elas estão desafiando a natureza. Porque biologicamente falando, existem muitos graus entre fêmea e macho [...]". A discursividade binária, portanto, esbarra em limites e suprime a existência de corpos com configurações físicas tidas como masculina, feminina, como ambas as configurações ou como nenhuma delas.

\footnotetext{
${ }^{4}$ A manifestação epigenética é um conjunto de mecanismos que regulam a forma como os genes se expressam, processa-se por intermédio de interações bioquímicas no DNA e na cromatina que, em consequência, geram mudanças fenotípicas sem que ocorram alterações na sequência de bases do DNA.

${ }^{5}$ Cisgênera é a pessoa que se identifica completamente com a genitalidade e o gênero atribuídos ao nascimento. Transgênera é a pessoa que não possui essa identificação e sua identidade de gênero não se conforma com o sexo dito biológico (mulheres trans, homens trans). Há também outras identidades não cisgêneras: pessoas transexuais, travestis e não binárias, por exemplo.
} 
Em meio à polissemia e à semântica do sexo, também é prudente considerar e rememorar que embora as configurações fêmea e macho manifestem-se estatisticamente com maior frequência e predominância, e por sobre elas recaiam os discursos de normalidade, outras materialidades pesam onto e biologicamente; há pessoas que nascem com disposições cromossômicas descoincidentes, genitálias ambíguas, fenótipos que mesclam características atribuídas às fêmeas e aos machos da espécie ou, ainda, aquelas que ao longo da vida desenvolvem arranjos físicos diferenciados. Essas "desafiam" o conhecimento científico e a semântica do dimorfismo sexual eleito como regra. Geram cadeias de efeitos, de indagações e de significados que fazem pensar sobre a instituída rigidez de duas categorias sexuais e possibilitam estilhaçar os enunciados cristalizados que defendem, de maneira limítrofe, as conformações físicas fêmea-macho / mulher-homem como as únicas existentes para seres humanos.

Para refutar qualquer tentativa de uma abordagem mais construcionista e abrangente sobre as materialidades sexuadas, as explicações enviesadas pelos discursos naturalizantes e deterministas regem as sexualidades por meio de conceitos, explicações e modos de disciplinarização. Há, sobretudo, o deslocamento e a sobreposição dos discursos científicos como argumentos de autoridade e de legitimação e, junto aos dispositivos de senso comum, de massa, religiosos e até mesmo pedagógicos, a fixação de regras biopolíticas para a população (controle dos corpos, controle dos grupos populacionais); nesse jogo de interlocuções e interações discursivas, emerge a biologia reconfigurada por atravessamentos culturais, justamente com a finalidade de fundar um "estatuto normal" para os corpos e para as identidades pessoais.

A Figura 1, por exemplo, ilustra as diferenciações biológicas sendo tracionadas como argumentos para se negarem as diferenças identitárias e para se legitimarem os essencialismos. Na tomada dos cromossomos como determinantes de sexo (e, equivocadamente, dos gêneros), condicionantes do desejo afetivo-sexual e carimbos determinísticos dos atravessamentos generificados, explicitam-se, inclusive com os enunciados apresentados, as incoerências e contradições de bases epistemológicas e conceituais das personagens em questão, especialmente se confrontadas com as explicações biológicas que considerei no corpo deste texto sobre o mosaico complexo da variação sexual. Ou, conforme postula Joan Scott (2012), as objeções das pessoas manifestantes na figura abaixo aglomeram-se em torno de enunciados que remetem a diferentes significados sociais, tais como: de poder (a visível dominação masculina), de orientação sexual (o apelo à heterossexualidade) e de incontestabilidade da diferença anato-biológica.

Esses enunciados essencialistas e compulsórios destacados na Figura 1 são exemplos de que, na regularidade do dispositivo da sexualidade, ao se vincular e se disseminar a existência de pessoas XX como fêmeas/mulheres e XY como machos/homens, fixa-se o sexo como força natural dominante, como destino fisiológico, psicológico e produtivo para mulheres e homens, e se atribuem conotações generificadas que tomam a biologia como 
condição determinante da vida social e como um substrato para gestar a intolerância e a segregação.

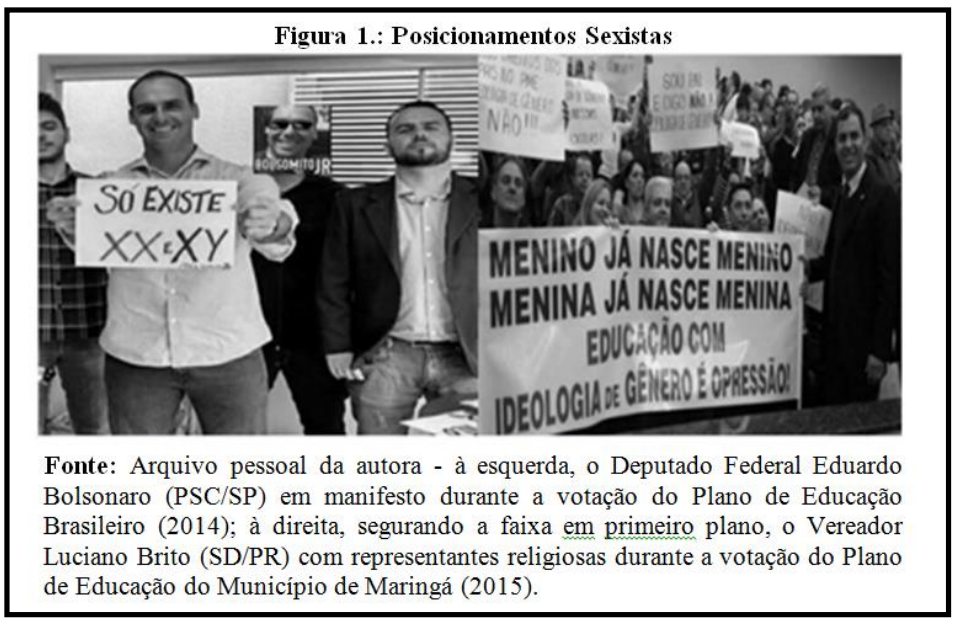

Ademais, conforme problematiza Henrietta Moore (1994, p. 813-814, tradução minha), há uma especial "uma especial dificuldade diante de argumentos desse tipo: eles implicam que a relação entre biologia e comportamento social pode ser compreendida como uma simples relação de causa e efeito".

As dissociações do senso estrito e desses enunciados discursivos que apelam ao argumento biológico e perfazem representações culturais apagam, ainda, outros arranjos genéticos e materialidades que podem ser denegadas pelas biopolíticas populacionais e por políticas de atendimento como, por exemplo: a Síndrome de Turner (X0); a Síndrome de Klinefelter (XX, XXYY, XXXY, XXXYY, XXXXY); a Síndrome de Jacobs (XYY nominados como super machos e $\mathrm{XXX}$ - reconhecidos como super fêmeas); pessoas $\mathrm{XY}$, porém portadoras da síndrome da insensibilização androgênica e, ainda, as $\mathrm{XX}$, mas com distúrbios de diferenciações sexuais testiculares, que não se encaixam na classificação binária do sexo e são variações cromossômicas possíveis dentro da espécie humana (Tabela 1).

Essas variações podem, inclusive, compreender diferenças genitais, gonadais e morfismos que, em termos de genitalidade e sexualidade, expressam traços fenotípicos ambíguos e/ou intersexuais. Outros aspectos, como interações hormonais e neurológicas, também não são trazidos à tona ante essa caracterização reducionista; e mais, não há como deixar de lado que algumas variações epigenéticas podem ocorrer em resposta ao ambiente e às interações sociais, direcionando mecanismos que configuram outras expressividades sexuais. 
Sensível a essa reclassificação, crítica de qualquer modalidade de binarismo e atenta aos deslizes limitantes da linguagem biológica, Anne Fausto-Sterling criou e apresenta o modelo baseado em cinco sexos (ou mais) para nos ajudar a pensar o que chama de transgressão biológica ou condição intersexual.

Tabela 1 - Tipos de intersexualidade

\begin{tabular}{|c|c|c|}
\hline NOME & CAUSA & QUADRO BÁSICO \\
\hline Hiperplasia adrenocortical congênita & 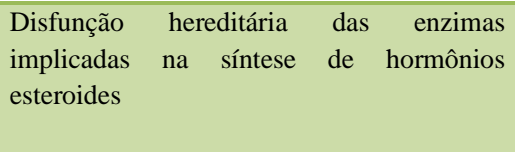 & $\begin{array}{l}\text { Nos recém-nascidos causa uma } \\
\text { masculinização genital leve ou severa, que } \\
\text { também pode se manifestar após o } \\
\text { nascimento ou na puberdade. }\end{array}$ \\
\hline Insensibilização androgênica & $\begin{array}{l}\text { Trocas hereditárias do receptor para a } \\
\text { testosterona localizada na superfície celular }\end{array}$ & \\
\hline Disgenesia Gonadal & Causas diversas & $\begin{array}{l}\text { Indivíduos cujas gônadas não se } \\
\text { desenvolvem adequadamente. } \\
\text { clínico heterogêneo. }\end{array}$ \\
\hline Hispopadias & $\begin{array}{l}\text { Causas diversas que incluem alterações do } \\
\text { metabolismo da testosterona. }\end{array}$ & $\begin{array}{l}\text { A uretra não se abre para o exterior na } \\
\text { glande do pênis. }\end{array}$ \\
\hline Síndrome de Turner & $\begin{array}{l}\text { Mulheres em cujo genótipo falta o segundo } \\
\text { cromossomo X (XO) }\end{array}$ & $\begin{array}{l}\text { Disgenesia gonadal em mulheres, sem } \\
\text { desenvolvimento de ovários e ausência de } \\
\text { caracteres secundários. Recomenda-se a } \\
\text { aplicação de estrógeno e hormônio de } \\
\text { crescimento }\end{array}$ \\
\hline Síndrome de Klinefelter & Presença de mais de um cromossomo X em & $\begin{array}{l}\text { Diasgenesia esterilizante, acompanhada de } \\
\text { crescimento das mamas na puberdade. }\end{array}$ \\
\hline
\end{tabular}

Adaptada de Anne Fausto Sterling, 1993

Conforme explica,

a literatura médica especializada usa o termo intersexo como um nome genérico para os três maiores subgrupos que misturam as características masculinas e femininas: os chamados hermafroditas verdadeiros, a quem chamo de hermes, que possuem um testículo e um ovário (gônadas e os receptáculos de produção de esperma e óvulos); os pseudohermafroditas masculinos (os 'mermes'), que têm testículos e alguns aspectos da genitália feminina, mas não ovários; e os pseudo hermafroditas femininos (as 'fermes'), que tem ovários e alguns aspectos da genitália masculina, porém lhes faltam os testículos. Cada uma dessas categorias é em si mesma complexa; a porcentagem de características masculinas ou femininas, por exemplo, pode variar enormemente entre os membros de um mesmo subgrupo. Além disso, a vida das pessoas em cada subgrupo, suas necessidades especiais e os seus problemas, atrações e repulsões permanecem inexploradas pela ciência. Mas com base no que é conhecido sobre eles, eu sugiro que os três intersexos, hermes, mermes e fermes merecem ser considerados sexos adicionais cada qual com seu próprio direito. Na verdade, eu ia argumentar também que o sexo é um continuum vasto e infinitamente maleável que desafia as limitações, mesmo que consideremos cinco categorias (FAUSTO-STERLING, 1993, p.21, tradução minha).

O objetivo dessa classificação é tanto evidenciar a materialidade intersexual quanto refutar os binarismos criados por leituras equivocadas da biologia. 
Sendo o sexo situacional, também no âmbito das interações biológicas, quase tudo que se queira dizer sobre ele - da forma que for compreendido - já contém um posicionamento ou reivindicação a nos remeter para o gênero (LAQUEUR, 2001, p. 23). Dito com outras palavras: tanto os alinhamentos para se compreender os sentidos dados ao sexo, no que diz respeito às distinções físicas e biológicas elaboradas pela linguagem científica na sua tentativa de enunciar o observável da natureza, como os alinhamentos para se saber dos gêneros são atravessados por jogos de significação.

Isto posto, as realidades acessadas para explicar o mundo serão sempre realidades sob elaboração nas e circunscritas às relações de poder e saber. Essa afirmação também é recobrada por Anne Fausto-Sterling para discordar das posições oficializadas pela medicina sobre os corpos intersexuais - em intervenções cirúrgicas decididas por equipes especializadas, após o nascimento de pessoas com genitálias ambíguas ou durante o desenvolvimento de suas vidas, opta-se pela preservação das potências corporais que poderão culminar em processos reprodutivos e pelo estatuto heteronormativo nesses corpos, desconsiderando, muitas vezes, as marcações subjetivas de gêneros e de desejos dessas pessoas e a possibilidade de, quiçá, conviverem com seus corpos plurissêmicos.

Longe, contudo, de negar as bio-logias dos corpos, é possível, então, considerar que em termos humanos, ou em termos das significações traçadas pela linguagem, é

[...] útil distinguir entre categorias sociais e biológicas. 'Homem' e 'mulher' são categorias sociais. Temos a liberdade de decidir quem conta como homem e quem conta como mulher. O critério muda de tempos em tempos. [...] Não temos a mesma liberdade com categorias biológicas. 'Macho' e 'fêmea' são categorias biológicas, e o critério para classificar um organismo como macho ou fêmea tem que funcionar para vermes e baleias, algas marinhas e sequóias. Quando se trata de humanos, o critério biológico de macho e de fêmea não coincide $100 \%$ com o critério social atual de homem e mulher (ROUGHGARDEN, 2005, p. 24-25).

Logicamente não estamos imunes aos fatores naturais, e até aceitamos que nas descrições sobre os filos, as classes e nos empregos taxonômicos o conhecimento das categorias biológicas empreste definições às sexualidades, aos sexos e aos sentidos sociais dos gêneros. Também não estamos imunes aos fatores culturais, e nem à história, pois os corpos, as vidas e as sexualidades são fundamentos epistêmicos conectados a ordens e a temporalidades sociais muito específicas. Nesse sentido, não há, pois, outra maneira de se falar sobre sexo/gênero que não seja a via discursiva do sexo/gênero, da linguagem, dos significados criados e em trânsito de uma biologia que se imbrica na cultura. Problematizar essa discursividade possibilita, portanto, chacoalhar o predomínio biológico de causa e efeito e desestabilizar o conjunto de sentidos e significados do sexo que 
permitiu agrupar, de acordo com uma unidade artificial, elementos anatômicos, funções biológicas, condutas, sensações e prazeres e permitiu fazer funcionar esta unidade fictícia como princípio causal [...] Além disso, apresentando-se unitariamente como anatomia e falha, como função e latência, como instinto e sentido, pôde marcar a linha de contato entre um saber sobre a sexualidade humana e as ciências biológicas da reprodução; desse modo aquele saber, sem nada receber realmente dessas últimas - salvo algumas analogias incertas e uns poucos conceitos transplantados - ganhou, por privilégio de vizinhança, uma garantia de quase cientificidade; mas através dessa mesma vizinhança, certos conteúdos da biologia e da fisiologia puderam servir de princípio de normalidade à sexualidade humana (FOUCAULT, 1988, p. 144).

Além disso, as verdades das compreensões e as verdades dos corpos não foram apenas investigadas pela biologia, mas instituídas. São necessários critérios e exercícios de problematização para não se deixar capturar pelas tentações de seus superficialismos e de seus determinismos.

A medicina ocidental, por exemplo, necessitou criar, após a Revolução Francesa e a declaração dos direitos universais, um novo modelo genital que se despediu da lógica do sexo único de Galeno e da Idade Média. No modelo único, considerava-se a mulher como o espelhamento imperfeito do homem (seus órgãos sexuais eram os mesmos - os ovários eram os testículos, a vagina o pênis, assim por diante - porém com funções complementares invertidas, voltadas para dentro e sem os calores vitais necessários ao exercício da vida política). A partir do Século XVIII, insurgiu a ideia de dois sexos diferentes e separados. Essa concepção, todavia, foi moldada sobre uma nova verdade moral: as duas genitalidades estavam doravante decalcadas da diferenciação de mulheres e homens em função da ocupação de papéis sociais derivados de suas naturezas completamente distintas (LAQUEUR, 2001).

Durante séculos, os dados biológicos foram marcadores atrelados à representação das sexualidades em diferenças hierárquicas para os gêneros, os corpos, as classes e os pertencimentos culturais, e como ciência de origem, a biologia, conforme fluiu a história, ajudou a pré-escrever e a inscrever o que é designado por sexo e sexualidade, a diferença entre a mulher e o homem, entre o normal e o patológico, entre o aceito e o abjeto e o apagamento de materialidades sexuadas e generificadas não binárias. 


\section{Considerações Finais}

Debaixo de muitas camadas de biologismos sociais, deslizam as palavras, as coisas nominadas e as ordens ideológicas, e a biologia pode equivocadamente estar sendo usada como uma maneira única e persuasiva de explicar as visíveis desigualdades sociais, os sexismos preconceituosos e a universalização das condutas humanas como condições naturalmente determinadas, imutáveis e rígidas.

O que estou a discutir insere-se, portanto, em um posicionamento epistemológico que aponta para variações de concepções e significações sempre relacionais e que afirma ser impossível ancorar as acepções sobre sexo, sexualidade e gênero num único e consensual pensamento. As palavras possuem histórias e múltiplos usos, "elas não só são elaboradas para expressar certas concepções, mas elas também têm diferentes efeitos retóricos" (SCOTT, 2012, p. 331). Há que se considerar, no entanto, que os sentidos dados a esses e às práticas culturais vivenciadas pelas pessoas são significativamente variáveis, histórica e culturalmente falando.

Assim sendo, somos na superfície da pele e nas nossas dobras interiores, na maneira como nos apresentamos ao mundo e em nossas "bio-logias", indelevelmente povoados e compostos de/por linguagens. Essa é uma explicação emprestada de teorizações feministas que importam com a produção de um conhecimento biológico situado, questionado por pesquisas realizadas por mulheres e grupos considerados minoritários; tal explicação, sobretudo, pontua a dimensão cultural e os efeitos da linguagem nas categorias biológicas, lembrando que essas são também modelos gendrados nos mais diferentes grupos culturais e podem se estabelecer como ficções ou verdades transitórias relacionadas ao sistema saberpoder.

Considerando que o determinismo biológico constitui um importante argumento de autoridade e de apropriação para validar diferenças sociais entre mulheres, homens, pessoas com gêneros e sexualidades discordantes das normas patriarcais, heterossexuais e reprodutivas, tanto no meio acadêmico quanto nas instâncias culturais, é importante destacar que leituras superficiais da biologia contribuem para a construção de diferenças entre pessoas no que tange às questões de gênero, sexo e de sexualidade. Muitas dessas leituras confluem para os currículos escolares como ordenamentos de saber e podem, inclusive, serem subsídios para o preconceito, a discriminação e a segregação social. Dada à força movente que a biologia apresenta na ordem do cotidiano, a problematização de seus enunciados é também a razão para se apontar que os discursos biológicos ainda constituem um campo discursivo privilegiado e criador da inteligibilidade e da aceitação dos corpos, ou seja, um campo a justificar a significação epistêmica dos gêneros, das sexualidades e das diferenças. 


\section{Referências}

BRITZMAN, D. Curiosidade, sexualidade e currículo. In: LOURO, Guacira Lopes. O corpo educado: pedagogia da sexualidade. Belo Horizonte: Autêntica, 2003. p.83-112.

BUTLER, J. Cuerpos que importan. Buenos Aires: Páidos, 2012.

CARVALHO, F. A. de. Os discursos biológicos na educação para os gêneros - as sexualidades - e as diferenças: aproximações e distanciamentos. 2018. $223 \mathrm{f}$. Tese (Doutorado em Educação para Ciência e a Matemática) - Universidade Estadual de Maringá, Maringá, 2018.

CARVALHO, F. A. de; BERTOLLI-FILHO, C. Sexualidade e educação sexual: enunciações e dispositivos nos contextos de ensino de ciências. In: ENCONTRO NACIONAL DE PESQUISA EM ENSINO DE CIÊNCIAS, 7., Campinas, SP, 2011. Anais... Campinas, SP: ABRAPEC/NUTES/UNICAMP, 2011. p. 1-10.

CARVALHO, F. A. de; LORENCINI-JÚNIOR, A. Os discursos biológicos para os gêneros, as sexualidades e as diferenças no Brasil: um panorama histórico. Revista Valore, Volta Redonda, n. 3 (ed. esp.), p. 575-586, 2018.

FAUSTO-STERLING, A. The Sciencies - The five sexes. New York: The New York Academy of Sciences, s/n, p. 19-25, mar. /apr., 1993. Disponível em: https://doi.org/10.1002/j.2326-1951.1993.tb03081.x

FAUSTO-STERLING, A. Cuerpos sexuados. Barcelona: Ed. Melusina, 2006.

FAUSTO-STERLING, A. Sex / Gender: biology in a social world. Lillington: Routledge, 2012

FOUCAULT, M. A história da sexualidade I. 14. ed. Rio de Janeiro: Graal, 1988.

FURLANI, J. Educação Sexual - possibilidades didáticas. In: LOURO, G.L. (Org.). Corpo, gênero e sexualidade. Petrópolis: Vozes, 2003. p. 73-91.

HARAWAY, D. Saberes localizados: a questão da ciência para o feminismo e o privilégio da perspectiva parcial. Cadernos Pagu, Campinas, nº. 5, p. 7-40, 1995.

HARDING, S. Ciencia y feminismo. Madrid: Ed. Morata S. L., 1996.

HARDING, S. Raça: doadores universais em uma cultura vampira. In: LESSA, P.;

GALINDO, D. (Org.). Relações multiespécies em rede. Maringá: EDUEM, 2017. p. 47-94.

KELLER, E. F. Qual foi o impacto do feminismo na ciência? Cadernos Pagu, Campinas, Unicamp, n. 27, p.13-34, jul./dez., 2006.

LAQUEUR, T. Inventando o sexo. Rio de Janeiro: Relume Dumará, 2001.

LIMA E SOUZA, A. M. F. Ensino de ciências: onde está o gênero? Revista Faced, Salvador, n.13, p.149-160, jan./jun., 2008. 
LÖWY, I. Ciências e gênero. In: HIRATA, H. et al. (Org.). Dicionário crítico do feminismo. São Paulo: Ed. UNESP, 2009. p. 40-44.

MARGULLIS, L; DORION, S. O que é sexo? Rio de Janeiro: Zahar, 2002.

MOORE, H. Understanding sex and gender. In: INGOLD, T. Companion encyclopedia of anthropology. London/New York: Routledge, 1994. p. 813-830.

ROUGHGARDEN, J. Evolução do gênero e da sexualidade. Londrina: Planta, 2005.

SANTOS, L. H. dos. A biologia tem uma história que não é natural. In: COSTA, M. V.

Estudos culturais em educação: mídia, brinquedo, biologia, literatura, cinema. Porto Alegre: Ed. Universidade/UFRGS, 2000. p. 229-256.

SCHIENBINGER, L.O feminismo mudou a ciência? Bauru: EDUSC, 2001.

SCOTT, J. Os usos e os abusos do gênero. Projeto História, n. 45, São Paulo, p. 327-351, 2012.

SENKEVICS, A.S.; POLIDORO; J.Z. Corpo, gênero e ciência: na interface entre biologia e sociedade. Revista da Biologia, São Paulo, n. 9, v. 1, p. 16-21, 2012. 